\title{
Recent Foraminifers from Oman Coast
}

\author{
Abdul Razak Siddiq Al-Sayigh ${ }^{1}$, Moza Muhanna Al Jahdhami ${ }^{1}$ and Ahmed Mohamed Muftah ${ }^{2}$ \\ 1. Department of Earth Sciences, College of Science, Sultan Qaboos University, Muscat 132, Sultanate of Oman \\ 2. Department of Earth Sciences, Faculty of Science, University of Benghazi, Benghazi 9480, Libya
}

\begin{abstract}
This study presents the first documentation work on recent benthic foraminifers of Oman coasts, especially of the northern part of Sultanate at Sawadi and the southern part at Janoof Tidal Creek near Taqah-Salalah beach. Eleven samples were collected from both localities. Twenty-nine species of benthonic Foraminifera belonging to 20 genera are retrieved, identified and illustrated herein. The study areas show the interaction in land and sea. Lagoons with normal marine hypersaline inhabited with sea grass and Mangrove-swamps. Mainly calcareous porcellaneous and hyaline walled foraminifers are abundant. Environmentally, the Janoof Tidal Creek shows better condition than Sawadi Tidal Creek as reflected by the more diverse and high abundance of foraminiferal taxa at the former locality. Both water bodies are free of toxic-heavy elements as evidenced by the lack of any abnormal foraminiferal test.
\end{abstract}

Key words: Mangrove, foraminifera, tidal creek, sawadi, muscat.

\section{Introduction}

The Sultanate of Oman located at the eastern extremity of the Arabian Peninsula covering an area of $309,500 \mathrm{~km}^{2}$ enclosed between latitudes $16.40^{\circ} \mathrm{N}$ and $26.20^{\circ} \mathrm{N}$ and longitudes $51.50^{\circ} \mathrm{E}$ and $59.40^{\circ} \mathrm{E}$. Oman is flanked by the United Arab Emirates and Ruba' Al Khali of Saudi Arabia to the west, Yemen to the south, the straits of Hormuz (Iran) to the north and the Oman Sea to the east (Fig. 1a). This study aimed to document the retrieved foraminiferal taxa from Oman coast, in particular Sawadi and Janoof areas, and to monitor the pollution in these two near shore areas.

\section{Material and Methods}

The samples were collected from two areas (Fig. 1 and Table 1); (1) eight samples (RS1 to RS8) were collected on July 4, 2009 from Sawadi area, which is located in Al Batinah region $85 \mathrm{~km}$ far from Muscat at the northeastern part of Sultanate Oman (2376'12.70" $\mathrm{N}$ and 57 79'28.92" E); (2) three samples (JNF1 to JNF3) were collected from the Janoof tidal creek, which is located in Janoof area 1,100 km from Muscat,

Corresponding author: Ahmed Mohamed Muftah, assistant professor, Ph.D., research field: paleontology, historical geology and environment. E-mail: a_muftah@yahoo.com. near Taqah-Salalah coast at the southern part of Sultanate Oman $\left(17^{\circ} 03^{\prime} 70.90^{\prime \prime} \mathrm{N}\right.$ and 54$\left.{ }^{\circ} 37^{\prime} 46.85^{\prime \prime} \mathrm{E}\right)$.

Sawadi tidal creek and Janoof Tidal Creek sediments are largely deposited by action of low water current circulation, since they were restricted by sand bar in inner lagoon. The offshore bars are usually subjected to waves which leading to the formation of highly agitated area.

The bulk sediments of the collected samples consist of sands.

The Sawadi Tidal Creek sands are of medium to very fine sizes and well sorted grains (Fig. 2). Meanwhile, the Janoof Tidal Creek sands are of fine grain size (Fig. 2). However, the granules and very coarse grains (gastropods, bryozoans and bivalves shells or their debris) are mainly linked to beach and foreshore areas. The distribution of these sediment types were found to be related to the water depth as well as to the geographic location. Since the beach and the shallower parts of the area were exposed to agitated force by waves, where coarse and medium sand were found in significant size to the fine fraction. The various size fractions percentages of the collected sediments from the Sawadi Tidal Creek (Figs. 2b and 2c) as well as the Janoof Tidal Creek (Fig. 2d) were 

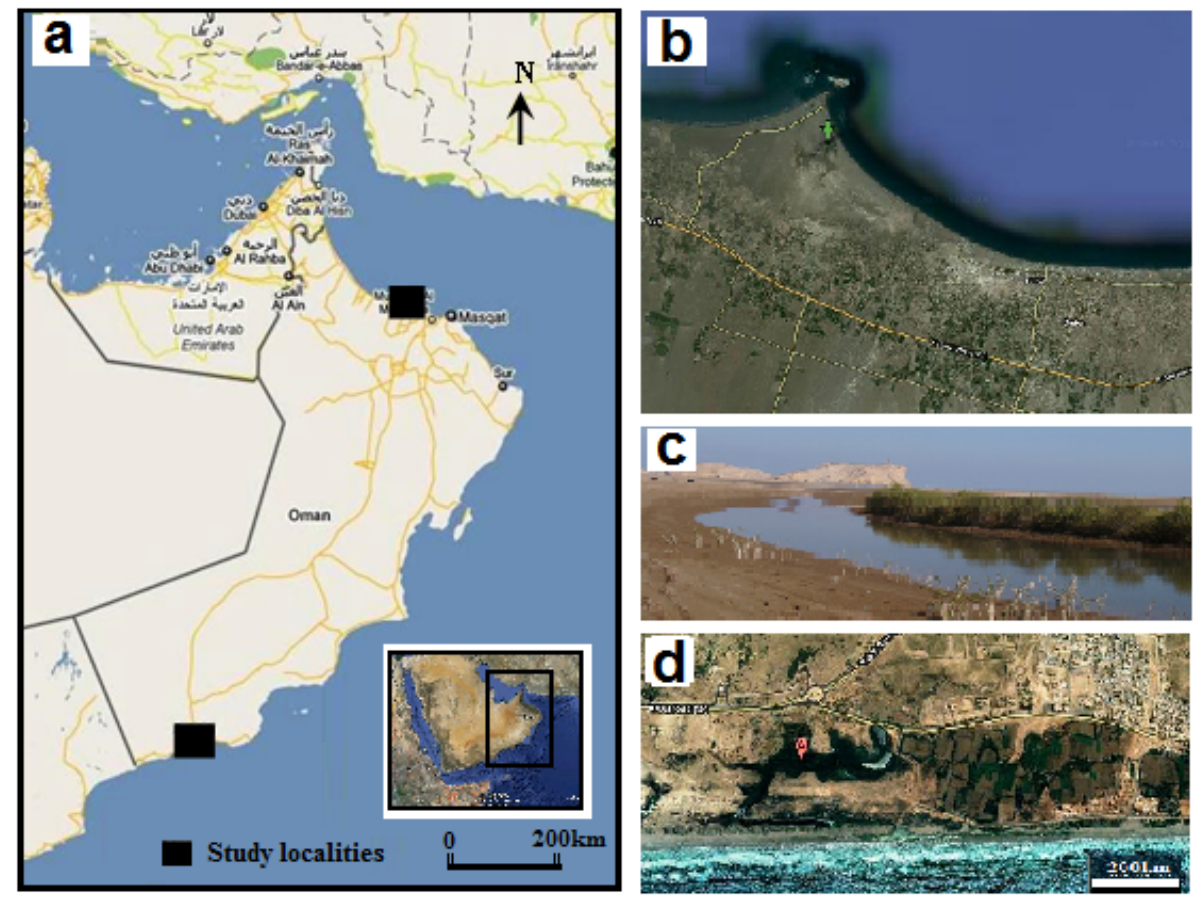

Fig. 1 (a) Location map of Sultanate of Oman shows the two studied localities; (b) Satellite image of the Sawadi tidal creek; (c) General view shows the sampled Mangroves at Sawadi Beach; and (d) Satellite image shows Janoof tidal creek near Taqah beach.

Table 1 Samples against each locality with brief remarks.

\begin{tabular}{ll}
\hline Sample No. & Remarks \\
\hline RS1 & Mid-channel (slightly Sandy) \\
RS2 & Tidal bank, branched channel \\
RS3 & Tidal bank \\
RS4 & Top 0-3cm surface mud Mangroves \\
RS5 & Mangroves área reduced bank ( ${ }_{2}$ S smell) \\
RS6 & Mangroves 3 \\
RS7 & Distance cannel 2, Inner Khor región, \\
RS8 & mid-Cannel pool 0-5cm mud \\
JNF1 & Distance cannel 1, mid-Cannel area 3 \\
JNF2 & Entrance of Khor \\
JNF3 & Tidal bank \\
\hline
\end{tabular}

analyzed to understand the depositional mechanism and the distribution of foraminiferal assemblages.

\section{Taxonomical Notes}

\subsection{Foraminiferal}

Foraminifers (the tool used in this study) are unicellular microfaunas moving by means of granuloreticulose pseudopodia. $(0.1-1.00 \mathrm{~mm})$. They are widely distributed in space and time in almost all marine environments [1]. Foraminifers are restricted to marine and brackish waters, and benthic forms are particularly abundant in shallow coastal seas, therefore, they are very useful in the ecological and environmental studies, as well as detecting the pollution risk in the coastal water bodies [2]. Pollution of marine environment by the heavy metals had been studied by several workers including Alve [3]. Furthermore, the impact of the concentration of specific heavy metal/metals on foraminiferal test has been discussed by Yanko. et al. [4]. The study of Muftah [5] is an example of the polluted coast as indicated by the presence of some abnormal foraminiferal tests from Libyan coast. However, several studies have been published in relation to Mangrove swamps and nearshore environments $[6,7,10]$. Foraminifers with coiled tests are abundant in the region with mangrove forest muddy and clayey beds, meanwhile, further offshore, uniserial, biserial or triserial tests exists with more abundant and diversity [6].

The collected samples from both localities are tried for their foraminiferal contents (Table 1). Among 

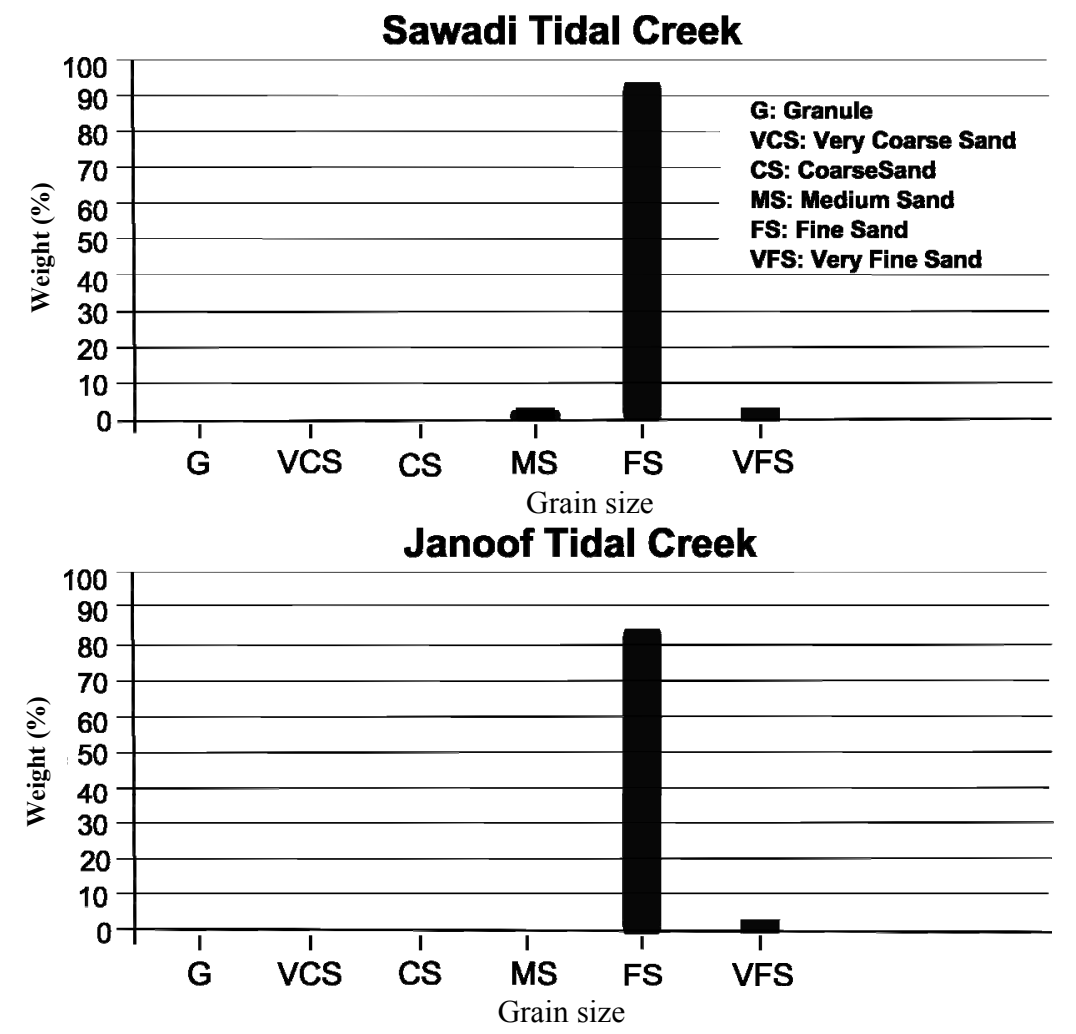

Fig. 2 Histogram of the average grain sizes distribution of the various textural classes.

29 species of benthic foraminifers identified in the material collected, only Ammonia, Elphidium, Quinqueloculina, Triloculina Parrellina and Cibicides were ever numerically dominant although several other genera were abundant (e.g., Amphistegina, Pseudotriloculina, Borelis, Troculina, Siphonaperta, Adelosina, Nonion, Rosalina and Textularia).

Twenty-nine species of benthic foraminifers belonging to 15 genera are listed alphabetically in Table 2 by family sensu as illustrated in Figs. 3 and 4 [8].

\subsection{Foraminiferal Analysis}

\subsubsection{Foraminiferal Distribution of Sawadi Tidal} Creek

Eight sediment samples were collected from Sawadi Tidal Creek. They show the highest frequency of total foraminiferal test from the sediments around Mangroves and inner khor region in Sawadi. However, the low frequency of foraminiferal tests was found in the entrance of the khor and in tidal bank areas. Foraminiferal tests of the inner part of Khor were smaller than those of near shore area. However, some tests were found broken with sediments from the entrance of the Khor. More than 13 different foraminiferal species belonging to eight genera were identified in this area. The genera distributed as follows: Elphidium (40\%), Pseudotriloculina (20\%), Ammonia (18\%), Nonion (11\%), Quinqueloculina (4\%), Siphonaperta (3\%), Adelosina (2\%), and Taxtularia (2\%). Elphidium constituted the highest percentage of the reported taxa in this area, followed by Pseudotriloculina, Ammonia and Nonion. While Quinqueloculina, Siphonaperta, Adelosina and Taxtularia constituted less than $10 \%$.

3.2.2 Foraminiferal Distribution of Janoof Tidal Creek

Three sediments samples were collected from Janoof Tidal Creek. They are very rich in foraminifers. The highest frequency of total foraminiferal tests was recognized in the sediments of the inner Khor region. However, the low frequency of foraminiferal tests was found in sandy channels near coast area. Foraminiferal 
Table 2 The classification and distributional summary of the reported foraminifers at both localities.

\begin{tabular}{|c|c|c|c|c|}
\hline \multirow{2}{*}{ Family } & \multirow{2}{*}{ Species and (Figure No.) } & \multicolumn{2}{|c|}{ Materials } & \multirow{2}{*}{ Spatial distribution } \\
\hline & & Janoof & Sawadi & \\
\hline Alveolinidae & Borelis schlumbergeri (Fig.3a) & $14(2-3)$ & & Southern Oman, Janoof and Salalah coasts \\
\hline \multirow{3}{*}{ Ammoniidae } & Ammonia beccarii (Fig. 3b) & $53(1-3)$ & $32(4,5,7)$ & $\begin{array}{l}\text { Southern Oman, Salalah and Northern Oman, } \\
\text { Batinah coasts }\end{array}$ \\
\hline & Ammonia convexa (Fig. 3c) & $78(1-3)$ & $23(4,5,8)$ & $\begin{array}{l}\text { Southern Oman, Salalah and Northern Oman } \\
\text { Batinah coasts }\end{array}$ \\
\hline & Ammonia topida (Fig. 3d) & & $15(3,5)$ & Northern Oman, Batinah coasts \\
\hline \multirow{2}{*}{ Amphisteginidae } & Amphistegina radiata (Fig. 3e) & $57(1-3)$ & & Southern Oman, Janoof and Salalah coasts \\
\hline & Amphistegina papillosa (Fig. 3f) & $44(1-3)$ & & Southern Oman, Janoof and Salalah coasts \\
\hline Cibicididae & Cibicides mabahethi (Fig. 3g) & $63(1-3)$ & & Southern Oman, Janoof and Salalah coasts \\
\hline Discorbidae & Trochulina sp. (Fig. 3h) & $21(2-3)$ & & Southern Oman, Janoof and Salalah coasts \\
\hline \multirow{9}{*}{ Elphidiidae } & Elphidium advenum (Fig. 3i) & $61(1-3)$ & $36(5,6,8)$ & $\begin{array}{l}\text { Southern Oman, Salalah Coast and Northern Oman, } \\
\text { Batinah coast }\end{array}$ \\
\hline & Elphidium limbatum (Fig. 3j) & $31(2-3)$ & & Southern Oman, Salalah Coast \\
\hline & Elphidium williamsoni (Fig. 3k) & $74(1-3)$ & $53(4,5,7,8)$ & $\begin{array}{l}\text { Southern Oman, Salalah Coast and Northern Oman, } \\
\text { Batinah coast }\end{array}$ \\
\hline & Elphidium spp. & $80(1-3)$ & $43(6,8)$ & $\begin{array}{l}\text { Southern Oman, Salalah Coast and Northern Oman, } \\
\text { Batinah coast }\end{array}$ \\
\hline & Parrellina cf.P. milletti (Fig. 31) & $18(1-3)$ & & Northern Oman, Batinah Coast \\
\hline & Triloculina affinis (Figs. 4a,b) & $92(1-3)$ & & Southern Oman, Janoof and Salalah coasts \\
\hline & Triloculina cf. T. serrulata (Fig. 4c) & $26(2-3)$ & & Southern Oman, Janoof and Salalah coasts \\
\hline & Triloculina cf. T. trigonula (Fig. 4d) & $78(1-3)$ & & Southern Oman, Janoof and Salalah coasts \\
\hline & $\begin{array}{l}\text { Quinqueloculina } \text { cf. } Q \text {. } \\
\text { multimarginata (Fig. } 4 \mathrm{e} \text { ) }\end{array}$ & $37(1-3)$ & & Southern Oman, Janoof and Salalah coasts \\
\hline \multirow[t]{6}{*}{ Hauerinidae } & Quinqueloculina parvula (Fig. 4f) & $29(1-3)$ & & Southern Oman, Janoof and Salalah coasts \\
\hline & Quinqueloculina patagonica (Fig. 4g) & $29(2-3)$ & & Southern Oman, Janoof and Salalah coasts \\
\hline & Quinqueloculina poeyana (Fig. 4h) & & $24(5,6,8)$ & Northern Oman, Sawadi, Batinah coast \\
\hline & Quinqueloculina ungeriana (Fig. 4i) & $5(3)$ & & Southern Oman, Janoof and Salalah coasts \\
\hline & Pseudotriloculina subgranulata (Fig. $4 \mathrm{j}$ ) & & $69(5,8)$ & Northern Oman, Sawadi, Batinah coast \\
\hline & Siphonaperta pittensis (Fig. 4k) & & $11(2,7)$ & Northern Oman, Sawadi, Batinah coast \\
\hline Spiroloculinidae & Adelosina sp. (Figs. 41 and $4 \mathrm{~m}$ ) & & $10(4,6,8)$ & Northern Oman, Sawadi, Batinah coast \\
\hline Nonionidae & Nonion sp. (Fig. 4n) & $45(1-3)$ & $41(6,8)$ & $\begin{array}{l}\text { Southern Oman, Janoof and Northern Oman, } \\
\text { Batinah coasts }\end{array}$ \\
\hline Rosalinidae & Rosalina bradyi (Fig. 4o) & $22(2-3)$ & & Southern Oman, Janoof and Salalah coasts \\
\hline Textulariidae & Textularia agglutinans (Fig. $4 \mathrm{p}$ ) & $16(1-3)$ & $8(5,8)$ & $\begin{array}{l}\text { Southern Oman, Janoof and Northern Oman, } \\
\text { Sawadi,Batinah coasts }\end{array}$ \\
\hline
\end{tabular}

tests of near coast areas were highly fragmented. In addition, they contain numerous gastropods and ostracods. Twenty-two different foraminiferal species belonging to 11 genera were identified in this area. The genera distributed are as follows: Elphidium (25.5\%), Triloculina (19.5\%), Ammonia (14\%), Amphistegina (10.5), Quinqueloculina (10.4\%), Cibicides (6.5\%), Nonion (4.6\%), Rosalina (2.3\%), Trochulina (2\%), Parrellina (1.8), Taxtularia (1.6\%) and Borelis (1.3\%). Elphidium and Triloculina constituted the highest percentage of the reported taxa in this area.

This is followed by Ammonia, Amphistegina, Quinqueloculina, Cibicides and Nonion. However, Rosalina, Trochulina, Parrellina, Taxtularia and Borelis constitute less than $10 \%$ of the total foraminiferal genera in this area.

The samples from Janoof Tidal Creek showed higher in diversity and abundance of foraminiferal species than from Sawadi Tidal Creek. It may be explained by that Janoof have better seawater exchange than Sawadi. However, high diversity was 

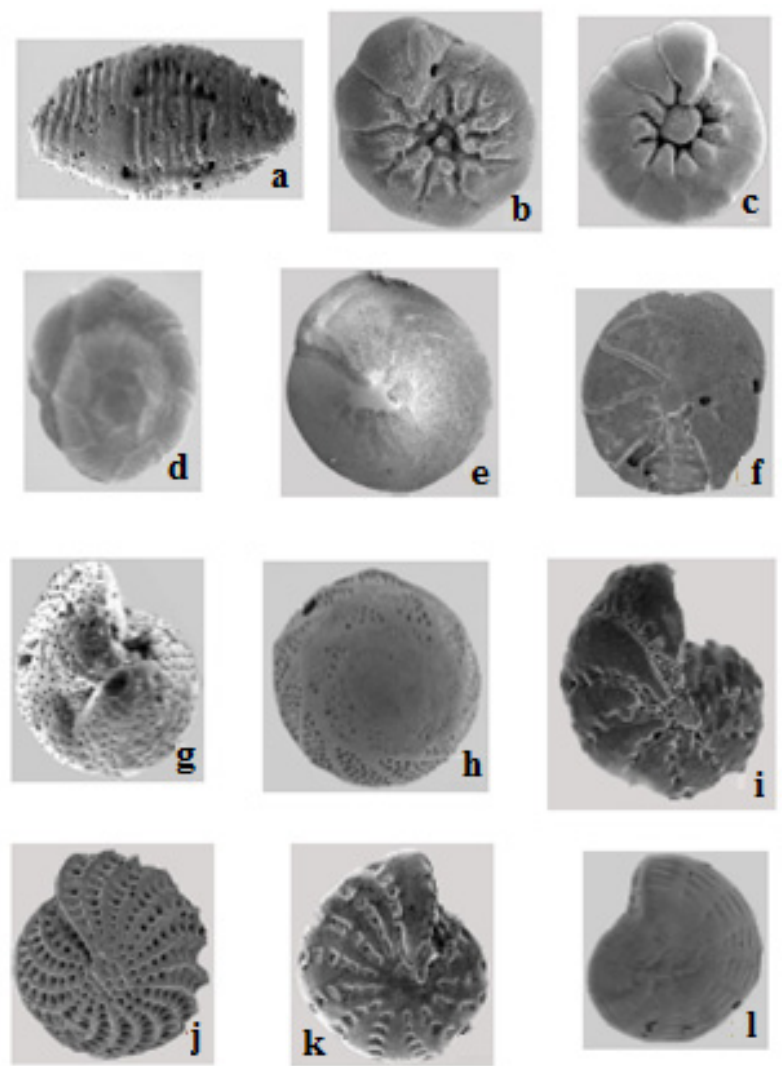

Fig. 3 Foraminifera plate: (a) Borelis schlumbergeri, X60; (b) Ammonia beccarii, ventral view, X60; (c) Ammonia convexa, ventral view, X50; (d) Ammonia tepida, dorsal view, X75; (e) Amphistegina radiata, ventral view, X50; (f) Amphistegina papillosa, ventral view, X70; (g) Cibicides mabahethi, ventral view, X50; (h) Trochulina sp., X200; (i) Elphidium advenum, X100; (j) Elphidium limbatum, X80; (k) Elphidium williamsoni, X50; (l) Parrellina cf. P. milletti, X100.

related to water exchange of Oxygen and the amount of nutrient in the environment [9]. In general, the majority of foraminifers concentrated at the inner part of Khor (lagoons) where it is away from the currents energy which may affected the characteristics of foraminiferal test such as wall thickness, size and shiny. Obviously, the studied areas represent the interaction of both land and sea water. Lagoons with normal marine hypersaline which have sea grass and Mangroves provide a substrate for epifaunal foraminifers. Certain species were observed in high percentages such as Elphidium and psuedotriloculina in Sawadi samples. On the other hand, at Janoof Tidal Creek, Elphidium, Triloculina and Ammonia are the
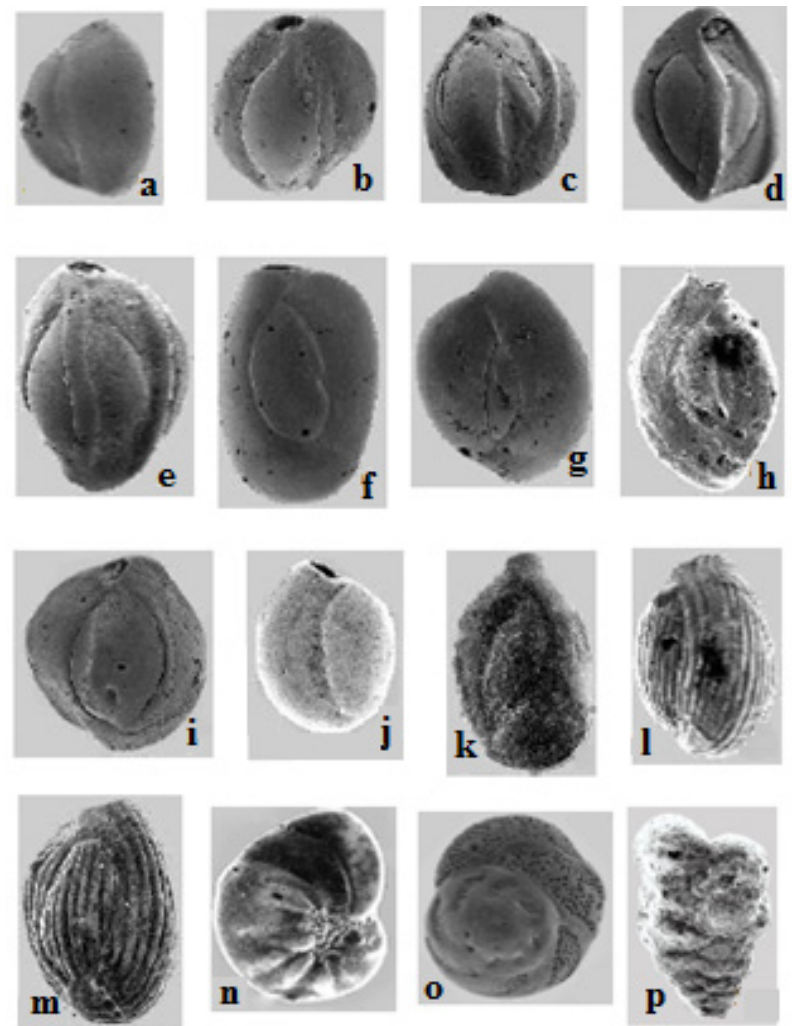

Fig. 4 Foraminifera plate: (a) Triloculina affinis, X50; (b) Triloculina affinis, X60; (c) Triloculina cf. T. serrulata, X70; (d) Triloculina cf. T. trigonula, X50; (e) Quinqueloculina cf. Q. multimarginata, X50; (f) Quinqueloculina parvula, X100; (g) Quinqueloculina patagonica, X50; (h) Quinqueloculina poeyana, X100; (i) Quinqueloculina ungeriana, X50; (j) Pseudotriloculina subgranulata, X50; (k) Siphonaperta pittensis, X70; (1) Adelosina sp., X50; (m) Adelosina sp., X60; (n) Nonion sp., ventral view, X80; (o) Rosalina bradyi, ventral view, X100; (p) Textularia agglutinans, X60.

dominant taxa; these measures may be due to the competition to colonize these two particular water depths and the subtropical geographic locations. The increase in diversity and abundance in the Janoof Tidal Creek is linked to the Mangroves setting [10].

\section{Conclusions}

The foraminifers of Oman coasts exhibit a wide range of depositional environments, from high energy at the entrance of the Khor and in tidal banks to low energy in the Mangroves, lagoons and inner Khor areas.

Twenty-nine recent benthic foraminiferal species are described and illustrated for the first time from 
Oman coasts.

The low species diversity and abundance in the samples of the Sawadi Tidal Creek area is due to low water exchange with the sea water in comparison with the Janoof Tidal Creek area.

The absence of the abnormal foraminiferal tests is environmentally positive sign, which indicates that both localities are free of any toxic pollutants.

\section{Acknowledgments}

Staff members of the Sultan Qaboos University are grateful for their encouragement and support during the field work and the laboratory work. Mr. Hamdan Al-Zidi and Dr. Abdalla Al-Zamel are highly appreciated for the unlimited help during this work.

\section{References}

[1] Cimerman, F., and Langer, M. R. 1991. "Mediterranean Foraminifera." Academia Scietiarium et Artium Slovenica (Ljubljana), Classis IV 30: 66-7.

[2] Phleger, F. B. 1970. "Foraminiferal Populations and Marsh Processes." Limno and Oceanogr. 15: 522-34.

[3] Alve, A. 1991. "Benthic Foraminiferal in Sediment Cores
Reflecting Heavy Metal Pollution in Sorfjord, Western Norway." Journal of Foraminiferal Research 21: 1-19.

[4] Yanko, V., Ahmad, M., and Kaminski, M. A. 1998. "Morphological Deformities of Benthic Foraminiferal Tests in Response to Pollution by Heavy Metals; Implications for Pollution Monitoring." Journal of Foraminiferal Research 28 (3): 177-200.

[5] Muftah, A. M. 2009. "Foraminifers as a Pollution Monitoring Tool: Case Example, Benghazi, Libya." Research Digest 4 (1): 3-7.

[6] Gregory, M. 1973. "Benthonic Foraminifera from a Mangrove Swamp, whangaparapara, Great Barrier Island." Tane 19: 193-204.

[7] Sohrabi-Mollayousefy, M., Tehrani, K. K. and Momeni, I. 2006. "Study of Benthic Foraminifera in Mangrove Ecosystem of Qeshm Island (Persian Gulf)." J. Sci. I. A. U (JSIAU) 16 (61): 10-19.

[8] Leoblich Jr., A. R. and Tappan, H. 1988. Foraminiferal Genera and Their Classification, 2 vols. New York: Van Nostrand Reinhold.

[9] Al-Zamel, A., Cherif, O. H., and Al-Rifaiy, I. A. 1996. "Tidal Creeks Foraminiferal Distribution in Khor Al-Mufateh and Khor Al-Mamlaha, Khiran Area, southeast Kuwait." Revue de Micropaleontologie 38 (1): 3-26

[10] Murray, J. W. 1973. Distribution and Ecology of Living Benthic Foraminiferids. Heinemann London. 